\title{
A FÓRMULA PATÉTICA DO FIM DE MUNDO NAS IMAGENS DO 11/9
}

\author{
THE PATHETIC FORMULA OF THE END OF THE WORLD IN 9/11
}

\author{
Alan Campos Araújo*
}

\begin{abstract}
Resumo
O presente artigo visa compreender as imagens do ataque às Torres Gêmeas em 2001 por pressupostos teóricos que levem em consideração tanto um aspecto afetivo delas como suas materialidades anacrônicas. Valendo-se dos estudos do teórico alemão Aby Warburg (bem como de seus comentadores - Didi-Huberman, Carlo Ginzburg e Philippe Alain-Michaud), o artigo parte do lugar de que as imagens do Onze de Setembro marcam o século XXI como nenhum outro grupo de imagens. Entretanto, ao redor delas, gravitam outras imagens que juntas apresentam uma cultura visual relativa a um fim de mundo. Portanto, se valendo de um método associativo imagético, o artigo investiga exemplos do cinema, da pintura e da fotografia, em relação com as imagens do 11 de Setembro, no intuito de debater suas materialidades e as diversas pontes culturais e históricas que um pensamento por imagem nos permite construir.
\end{abstract}

Palavras-chave: Fim do mundo. Imaginário. Cultura Visual. Aby Warburg. Fórmula Patética

\begin{abstract}
The present article aims to understand the images of the attack on the Twin Towers in 2001 by theoretical assumptions that take into account both their affective aspects of them and their anachronistic materialities. Drawing on the studies of the German theorist Aby Warburg (as well as his commentators - DidiHuberman, Carlo Ginzburg and Philippe Alain-Michaud), the article begins with the recognition that the images of September $11^{\text {th }}$ mark the $21^{\text {st }}$ century like no other group of images. However, other images gravitate around them, showing a visual culture relative to an end of the world. Therefore, using an associative imagery method, the article investigates examples of cinema, painting and photography in relation to the images of September $11^{\text {th }}$, in order to discuss their materialities and various cultural and historical bridges.
\end{abstract}

Keywords: End of the world. Imaginary. Visual culture. Aby Warburg. Pathetic formula.

Datas de submissão e aprovação do artigo

Submissão: $28 / 8 / 2018$

Aceito: $10 / 12 / 2019$

\footnotetext{
* Formado em Cinema e Audiovisual pela Universidade Federal de Pernambuco. Mestrando no Programa de Pós-Graduação em Comunicação (PPGCOM/UFPE). E-mail: alancampos1965@gmail.com.
} 


\section{INTRODUÇÃO}

Muito se conhece acerca dos eventos que sucederam os atentados às duas Torres Gêmeas em 11 de setembro de 2001: a política do governo Bush de guerra ao terror e o aumento considerável da vigilância em aeroportos, dentre outros acontecimentos que passaram a vigorar na cultura ocidental. É possível dizer que os dois aviões que atingiram Nova York naquela manhã (matando milhares de pessoas, seja no atentado ou por consequência dele, e ferindo outras milhares no processo) são responsáveis diretos por diversas mudanças políticas e sociais no âmbito contemporâneo que vão muito além dos Estados Unidos da América. Este trabalho não é sobre esse debate - que ainda é constantemente atualizado -, e sim sobre o regime que acionou tais novos agenciamentos culturais: o regime da imagem. Se pesquisarmos no Google acerca do 11/09, não encontraremos uma imagem dos atentados, mas várias, e de vários pontos de vista. Fotografias, imagens amadoras, imagens televisivas - aéreas ou não -, imagens computadorizadas, imagens de cinema. Devido à magnitude desse evento no início da era digital, o grande recolhedor dessas imagens não pode ser configurado em um rosto, mas em vários, muitas vezes anônimos e amadores.

Como o ataque pegou a todos de surpresa, não existiu um controle governamental de como lidar com ele. Sabe-se que o governo norte-americano vem jogando bombas em outras cidades e países há algumas décadas, como em Hiroshima e Nagasaki, na Guerra do Vietnã e na Guerra do Golfo. 0 tratamento desses genocídios é amplamente pensado tanto em um âmbito militar como em um âmbito imagético, revelando, em teoria, apenas o que recebe aval do governo. Porém um processo vem aumentando desde os conflitos do Vietnã, quando diversos fotógrafos e equipes audiovisuais foram registrar o conflito por conta própria, que é o da proliferação (tanto em seu registro, como em suas divulgações) e do descontrole das imagens dos fronts de guerra e de suas consequências devastadoras em um âmbito humano. Portanto, conforme as décadas avançam, o papel da imagem como ferramenta crítica contra os interesses institucionais tem aumentado.

0 que o ataque das Torres Gêmeas representa é a união de um evento grandioso ${ }^{1}$ em escopo com o ápice de um processo bastante contemporâneo que é a difusão dos dispositivos audiovisuais. Tendo em vista que o atentado ocorreu no início da era da Internet, pessoas filmaram e fotografaram exaustivamente, do céu e da terra, em diversos ângulos e sob uma variedade impressionante de cenas e pontos de vista. Sejam eles fotógrafos profissionais ou amadores curiosos, ou até cinegrafistas impressionados com o que acontecia diante deles, todos eles fizeram com que tais imagens impregnassem nosso imaginário contemporâneo. A cultura

\footnotetext{
${ }^{1}$ Levando em consideração que o outro grande ataque em solo americano, o de Pearl Harbor, em 1941, aconteceu longe das grandes metrópoles e em uma época onde não havia tantos dispositivos audiovisuais à disposição. Portanto, suas imagens foram difundidas de maneira mais controlada.
} 
ocidental é ávida por imagens. Não é difícil de imaginar que se o 11/09 tivesse ocorrido em 2019 haveria transmissões ao vivo no Facebook ou Stories no Instagram, talvez até das pessoas que estavam dentro dos prédios. Para além dos aspectos político-sociais que estavam em jogo nesse evento, que certamente já seriam suficientes para fazê-lo ser percebido midiaticamente, e dos diversos dispositivos que o difundiram enquanto imagem, existem outros aspectos que colocaram o ataque às Torres Gêmeas à parte de outros eventos midiáticos em nosso tempo.

Um deles é a escala que norteia o acontecimento: dois edifícios enormes (cada uma delas possuía quase 500 metros de altura) com centenas de pessoas em seus interiores, que foram atingidos por dois Boeings lotados, provocando explosões cinematográficas para, horas depois, as duas torres caírem e levantarem uma nuvem de poeira que se expandiu por vários quilômetros na cidade de Nova York. Registros dos desastres naturais como os tsunamis na Tailândia e no Japão respectivamente em 2004 e 2011 - são mais escassos por conta da dificuldade evidente de captá-los em progressão, e portanto suas repercussões midiáticas se configuraram bem mais em suas consequências do que no presente momento em que ocorreram. $\mathrm{O}$ ataque às Torres Gêmeas permitiu-se a uma maior entrada, por parte da mídia, de seu acontecimento, e, portanto, proporcionou um número maior de imagens.

Outra razão que diferencia o 11/09 de outros acontecimentos do séc. XXI foi a combinação de tudo que foi dito no último parágrafo com o seu caráter repentino. Ele não foi esperado, para o choque de todos que ali estavam e de muitos outros que acompanhavam através da televisão. Seria ingenuidade pensar que tais imagens não ofuscariam quaisquer outras em nível global naquele dia. Elas foram a materialização de coisas que eram imaginadas ou encenadas na arte, atraindo olhares por seus aspectos de um real extraordinário.

Prédios colossais queimando (Fig. 1) e, logo em seguida, vindo a baixo; nuvens espessas de poeira (Fig. 2), pessoas gritam, se escondem em carros; fumaças escuras que têm suas negritudes reforçadas pelo contrastado céu azul e limpo; pessoas cometem suicídio ao pular dos prédios em chamas; no chão, homens e mulheres são cobertos pelo cinza e branco da nuvem de poeira, outras fogem dela desesperadas (Fig.3); já em algumas fotografias, pessoas têm suas falas roubadas pelo caráter extraordinário do evento, mantêm-se petrificadas pela imagem, como se olhassem para uma medusa moderna (Fig. 4). Outras imagens denotam uma paisagem mais distanciada, em processo de alteração pelo fogo, imagens serenas que fazem carregam um sentimento de indiferença ao humano. Imagens da terra arrasada, marcada pela destruição e legada ao vento e ao pó.

Dentro de todas essas imagens do 11/09, opera um pensamento próprio e que vai muito além de seus contextos particulares, pois elas reportam a uma cultura visual que estava presente em nosso imaginário muito antes de elas existirem. Suas materialidades e limites de quadro fazem presente uma força que 
materializa uma emoção apocalíptica, uma reconfiguração da paisagem em relação ao ser humano, que por sua vez se encontra sob a ameaça de ser consumido por uma grande massa de ar de cor expressiva, ora branca, ora negra.

Figura 1 - Fotografia do avião atingindo a segunda torre

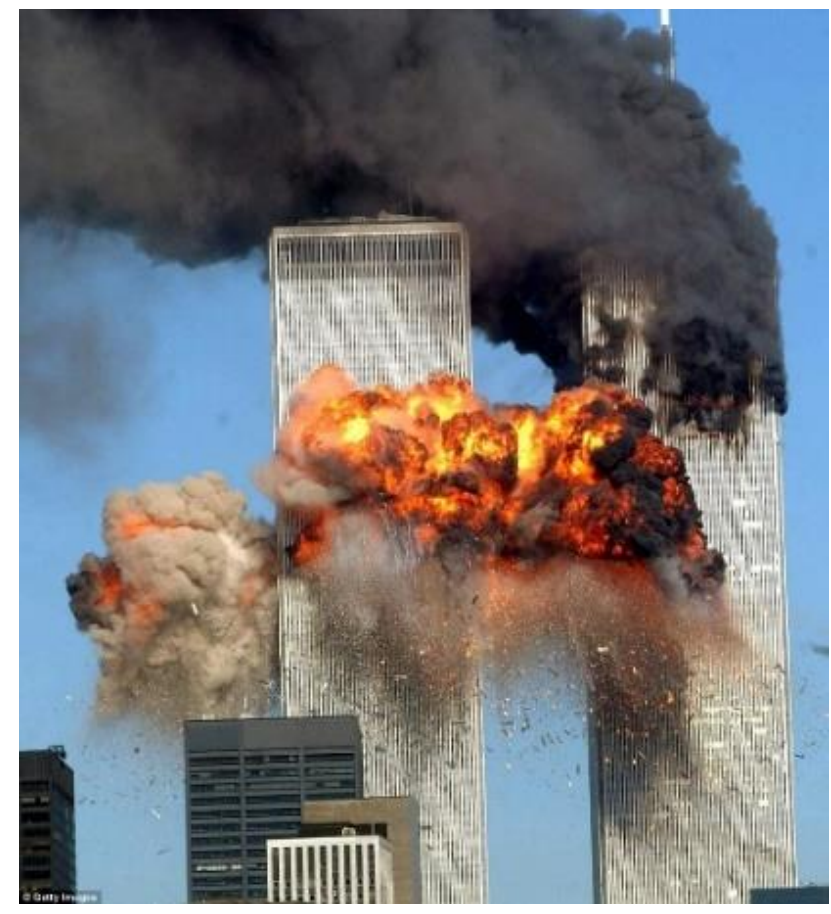

Fonte: Getty Images

Figura 2 - Visão aérea de Nova York após o atentado

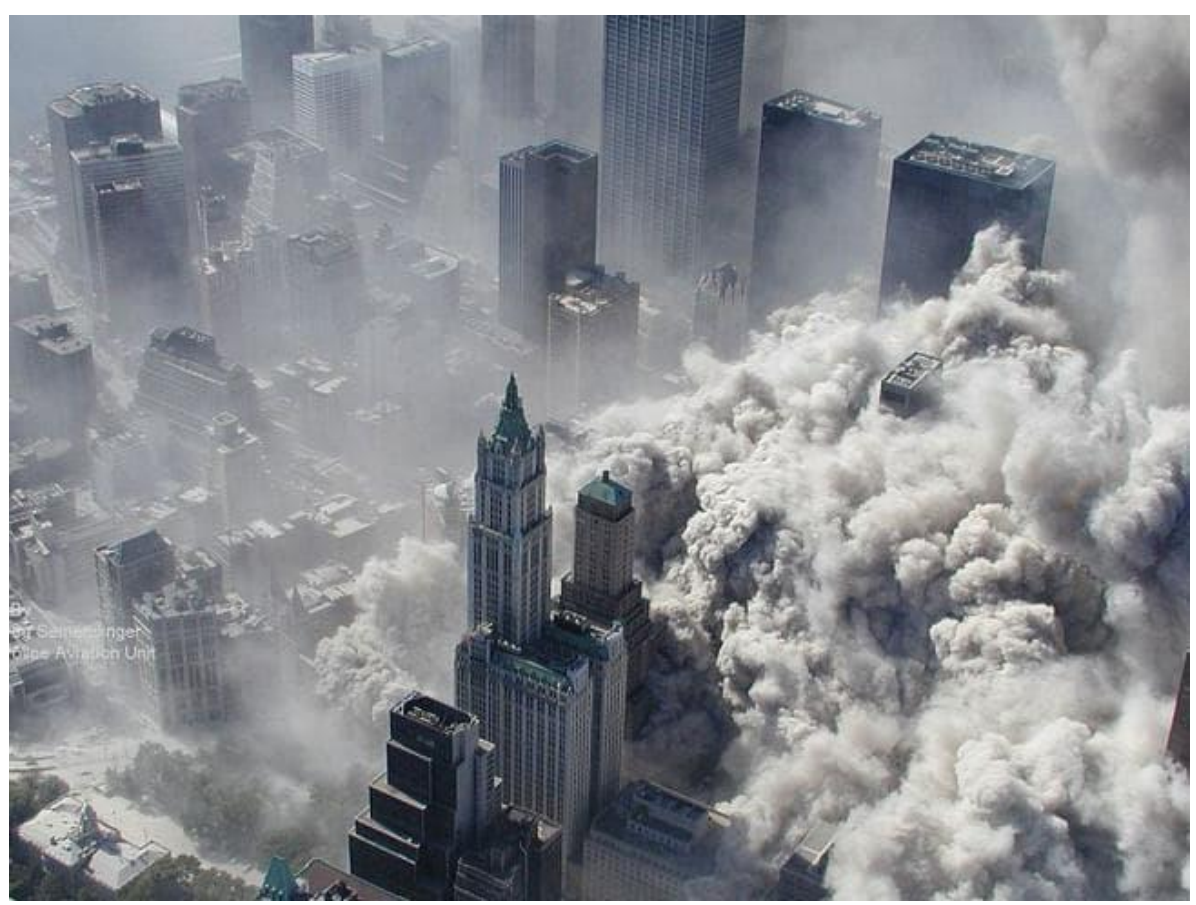

Fonte: NYPD via ABC News/AP

Revista Ícone, Recife, v. 18, n. 1, p. 1-21, jan/abr, 2020.

DOI: 10.34176/icone.v18i1.237960 ISSN Eletrônico: 2175-215X

http://www. periodicos.ufpe.br/revistas/icone 
Figura 3 - A nuvem de fumaça consome as ruas

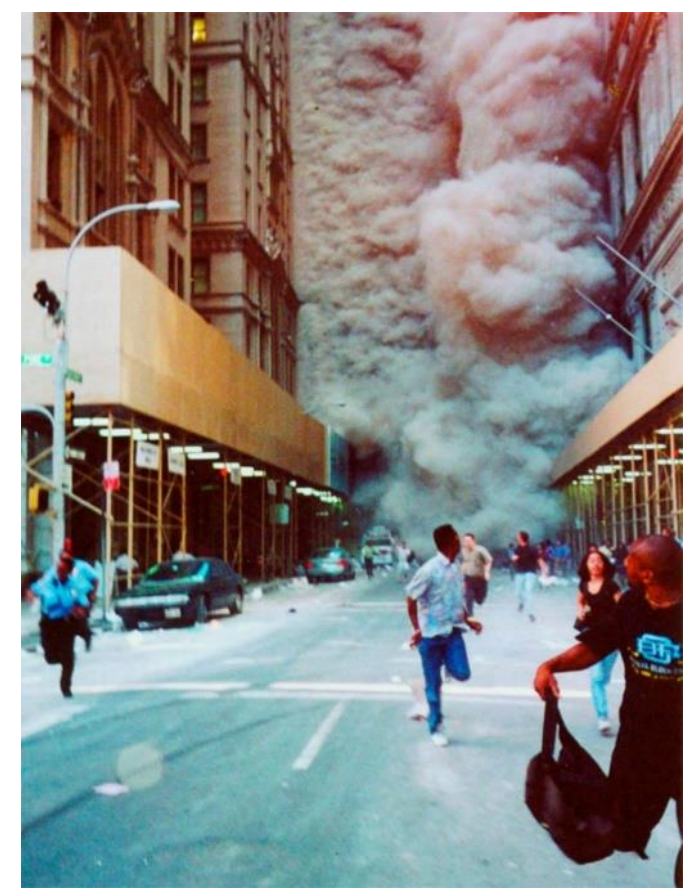

Fonte: Reprodução/Kelly Price

Figura 4 - Pessoas olham para as torres queimando

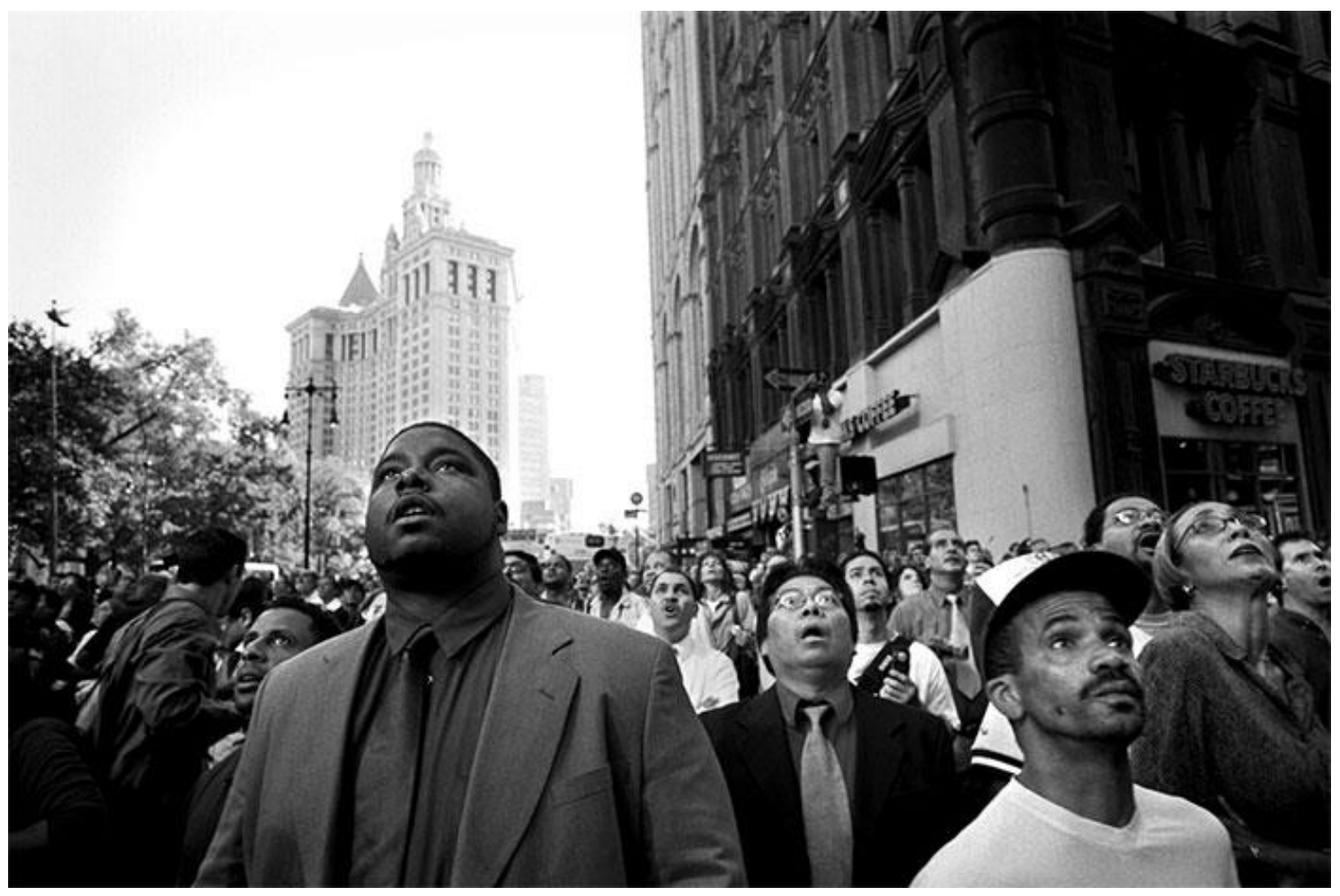

Fonte: Reprodução/Patrick Witty 
Nasce nessas imagens uma força que as atravessa, uma impressão de fim de mundo ${ }^{2}$. Meu intuito, portanto, é investigar uma cultura visual que gira em torno de tais imagens por afinidades íntimas.

\section{PENSAMENTO POR IMAGEM}

O que torna as imagens do atentado tão impactantes é a capacidade que elas têm de transbordar suas potências para além dos limites de seus quadros. Um pensamento próprio da imagem. Um terreno incapaz de se blindar da história e da memória. Entretanto, a narrativa da imagem não se configura em linha temporal positivista, e sim em uma de caráter centrífugo, quebrando um ideal histórico winckelmanniano, isto é, um modelo de "um esquema temporal obviamente biomórfico, estendido entre progresso e declínio, nascimento e decadência, vida e morte" (DIDI-HUBERMAN, 2013a, p. 18).

Aby Warburg foi um dos primeiros a entender que o tempo agenciado por uma imagem é mais complexo do que uma linha categoricamente rígida e facilmente identificada pelo pesquisador. 0 autor alemão dedicou-se a entender a imagem como sendo um campo imbricado de memória e cultura. Esse primeiro aspecto seria relativo a forças expressivas que se apresentam embutidas dentro das imagens. Warburg (2015) via o terreno imagético como sendo carregado de outros tempos, resquícios e sobrevivências de outras imagens. O teórico recorreu a um modelo de análise não cartesiano com suas Pathosformeln (Fórmulas de Pathos) ao perceber, em um desenho de Albert Durer intitulado A Morte de Orfeu (1494), a vontade do artista de chegar à expressão gestual da antiguidade. 0 desenho de Durer seria uma tentativa de embutir seu personagem de um movimento carregado de gestos, próprios da mesma fórmula afetiva de diversos desenhos da antiguidade que, ao serem vistos em paralelo por Warburg, se mostraram um terreno fecundo para reflexões.

A "fórmula de pathos" representa a aliança de duas componentes opostas: o pathos como reação corpórea, momentaneamente intensificada, de uma alma abalada; em face do ethos enquanto elemento caracterial constante, ao qual incumbe o controle das emoções como "fórmula". Esta intersecção, rica de conflitos, oferece o enquadramento para combinações sempre novas em que ambos os elementos, o pathos e também a fórmula, podem emergir distorcidos em si, e portanto, exigir e estimular a reflexão (BREDEKAMP, 2015, pp. 225-226).

0 constante estímulo à reflexão das Pathosformeln, como aponta Bredekamp, ocorre devido ao caráter surpreendente ao qual uma fórmula pode levar o pesquisador. Entre relações não óbvias e aparições inesperadas, o conceito trabalha por surpresas, distorcendo lugares canônicos. A materialização de

\footnotetext{
${ }^{2}$ Por "fim de mundo" eu referencio o momento em que o sujeito é retirado do tempo linear e é jogado em uma experiência mista de horror e atração, onde aquilo que compactuamos como "mundo" (regras sociais, lógicas de sentido) é momentaneamente suspenso em prol do arrebatamento violento.
} 
determinada imagem pode até não remeter de maneira instantânea a outras imagens, mas a partir dela emana uma força, um eco, uma reverberação que atua internamente no sujeito enquanto força patética. Tal energia permite constituir uma malha sensível de diferentes exemplos que denotam para o estudioso um campo de reflexões incansáveis acerca do pathos e dos gestos embutidos.

A noção de movimento nas imagens adquiriu vários contornos na obra warburguiana. Em sua tese sobre as pinturas "O Nascimento da Vênus" (1483) e "A Primavera” (1482), de Botticelli, o teórico alemão olhava para diversos detalhes de tais pinturas que despontavam para uma noção acerca do movimento nas imagens. Nesse aspecto, Warburg via tais quadros como frames congelados de uma cena carregada de ações e acontecimentos, quebrando com noções estáticas acerca das imagens e desenvolvendo um olhar preocupado com os gestos, com os movimentos, com os "antes e depois" das imagens.

O alemão falava em "perda da contemplação serena" (WARBURG apud MICHAUD, 2013, p. 88) por parte do espectador diante da imagem. A intervenção espectatorial, enxergada pelo teórico Philippe Alain-Michaud nessa perda de uma contemplação serena, traduz-se quase como se a imagem fosse um único frame de uma sucessão de muitas outras que se desenrolam no interior do sujeito que se coloca diante dela. 0 objeto se torna o único aporte físico de um momento inserido em uma história mais ampla que nasce a partir do espectador.

Warburg define a inscrição do movimento como uma persistência dos estados intermediários no deslocamento da figura: sua percepção exige, por parte daquele que olha, uma atenção identificadora - do tipo quase hipnótico -, graças à qual se produz uma troca entre sujeito e objeto (MICHAUD, 2013 p. 88).

À luz de Michaud e Warburg, as imagens do Onze de Setembro se tornam muito próximas dos nervos, pois seus diversos movimentos - explosões, suicídios, quedas das torres - se tornam inseparáveis de seus respectivos sons. A perda de um caráter passivo do espectador faz ressurgir, em partes, a experiência das imagens do atentado.

Em um aspecto cultural da imagem, o teórico buscava elucidar um novo processo histórico a partir de recorrências de símbolos em situações e objetos separados por séculos. Assim, imagens distintas conectadas por uma fórmula patética proporiam um novo modelo histórico.

O historiador italiano Carlo Ginzburg (2014) se vale do conceito das Pathosformeln como maneira de desenvolver uma nova narrativa a partir de objetos midiáticos. Em seu ensaio "Seu país precisa de você: um estudo de caso em iconografia política” (2014), o autor trabalha com as imagens de alistamento da primeira guerra mundial que se utilizam da figura imponente de dedo apontado para quem a vê, onde a mais conhecida é a do "Tio Sam" norte-americano, apesar da primeira de tais exemplos se tratar de uma imagem britânica do general Kitchener (Fig. 6) datada de 1914. Buscando entender a eficácia desse grupo de imagens, Ginzburg traça comparações dessa fórmula patética com as pinturas estilo 
Vera Icon ${ }^{3}$ do rosto do Cristo (Fig. 5). Para Ginzburg (2014), o chamado religioso de uma imagem é próximo do chamado às armas do outro exemplo. Ao relacionar essas duas imagens por uma fórmula patética que as atravessa, o historiador elucida um processo de transmissão imagética por vários séculos que ajuda a compreender, em partes, o porquê dessa imagem de Kitchener ser tão referenciada, reconfigurada e parodiada em nossa cultura ocidental. Para Ginzburg (2014), isso se dá porque em sua fórmula patética existe a ambivalência de uma figura religiosa que nos encara, levando-o a concluir que tal imagem de recrutamento possui imbricada dentro de si uma cultura visual muito antiga e enraizada nas imagens europeias.

Figuras 5 e 6 - Vera Icon de 1464 (por Dirk Bouts) e a imagem do Lord Kitchener
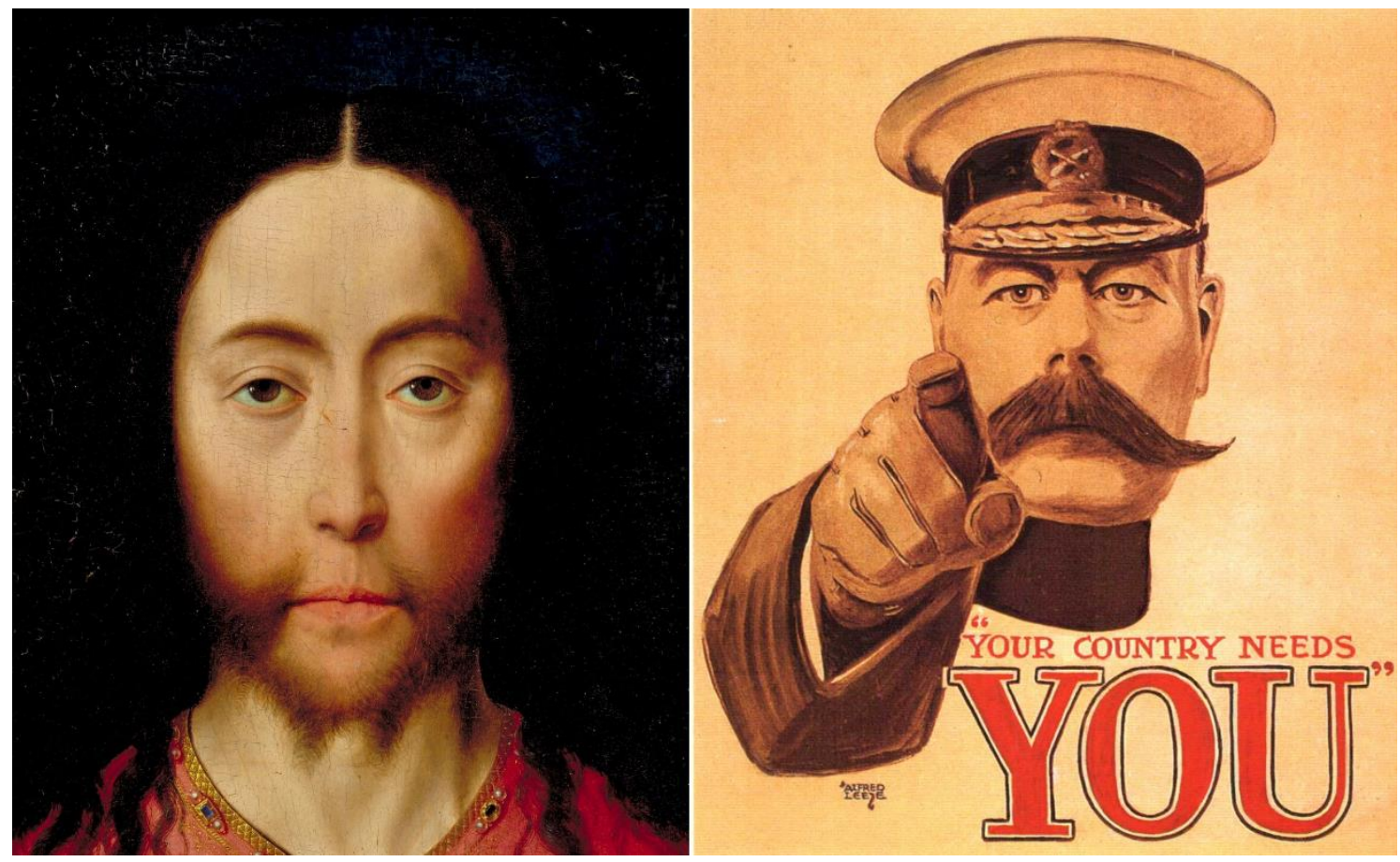

Fonte: Reprodução da internet

O conceito warburguiano das fórmulas patéticas nos convida a olhar para uma imagem como um gesto de uma coreografia maior, cujo percurso completo é impossível de ser traçado, pois se trata de um movimento que vai constantemente se atualizando com novas imagens.

Em seu último trabalho, o atlas Mnemosyne, Warburg reuniu em 79 pranchas cerca de mil imagens por um método simbólico e associativo de casos espalhados ao longo de séculos, na tentativa de elucidar uma "história de fantasmas para

3 Vera Icons são pinturas/representações do rosto de Cristo, possuindo esse nome em homenagem a Santa Verónica, que deu um véu para Jesus limpar o seu rosto - deixando sua impressão - quando ele caiu a caminho de sua crucificação. 
gente grande" (WARBURG apud MICHAUD, 2013, p. 301). Ou seja, uma história que visasse aparições de fenômenos que se enraizaram no âmago da cultura ocidental. Valendo-se de jornais, pinturas e esculturas, Warburg visou apresentar na “exuberante" (DIDI-HUBERMAN, 2013b, p. 12) forma do atlas as obsessões imagéticas que atravessavam nossa cultura.

Uma vez que não é orientada simplesmente, a montagem escapa às teleologias, torna visíveis as sobrevivências, os anacronismos, os encontros entre temporalidades contraditórias que afetam cada objeto, cada pessoa, cada gesto (DIDI-HUBERMAN, 2015, p. 301).

(Re)montar exaustivamente e agrupar imagens à primeira vista distintas se torna uma tarefa do pesquisador que procura entendê-las por um caminho que não as coloque como entidades unilaterais e de fácil compreensão. Para o teórico francês Didi-Huberman, a ideia de montagem ganha a importância de ferramenta metodológica para se chegar aos mistérios que habitam nossas imagens. Não no intuito de explicá-las, mas de problematizá-las para além de seus limites materiais e de perseguir, através de outras, seus efeitos, suas persistências e suas reverberações culturais.

Didi-Huberman, em seu lugar de apreciador e comentador da obra de Warburg, desenvolve a partir dos trabalhos do teórico alemão um tratamento com as imagens em relação a uma ideia de fantasma, ou seja, uma aparição, um pensar por imagens inseparável de um pensar por relação, operando por uma sensibilidade do pesquisador em reconhecer ou apostar em uma força de pathos em comum entre algumas imagens, priorizando a materialização expressiva de um fantasma em vários lugares. 0 método não pretende explicar uma origem ou prever os futuros de um fantasma, se contentando em identificar suas aparições, pondo um fim a um conhecimento isolado e, assim, elucidar uma nova narrativa, uma que seja própria do terreno imagético.

A pergunta "onde eu vi isso?"4 aparece, portanto, enquanto método. "Ver" aqui adquire a dupla função de identificar e sentir no âmbito de experimentar a imagem, se deixar à mercê dela e permitir que seus impactos sejam sentidos. Relacionar determinado caso com outros é tentar colocar suas engrenagens de pathos para funcionar. Um pensamento por imagem didi-hubermaniano tem como condição uma diluição das fronteiras entre as imagens de um fantasma, provocando uma imbricação de contextos, narrativas e mídias em prol de algo novo. 0 próprio francês coloca que as imagens não possuem voz em si, mas que é preciso colocá-las em relação (apud CAMPOS, 2017, p. 269), defendendo que o método que pense com elas não deseje explicá-las por via única, pois isso seria sacrificar sua condição natural para sobreviver em outras. Ou seja, indiretamente ou não, elas sempre irão

\footnotetext{
${ }^{4} \mathrm{O}$ próprio Warburg se fez tal pergunta quando viu a figura de uma Ninfa em uma obra de Ghirlandaio datada de 1485. Didi-Huberman fala extensivamente sobre isso em uma conferência dada em Portugal Disponível em: <https://vimeo.com/97822615>. Acesso em: 25 jul. 2018.
} 
se reportar a outras. Portanto, nosso interesse reside menos em descobrir a "verdade" de cada uma e mais em pensar como uma imagem pode ser relacionada com outros casos.

A imagem arde por causa da memória, o que significa que ela arde ainda, mesmo quando já não é senão cinza: maneira de dizer a sua essencial vocação para a sobrevivência, para o apesar de tudo. Mas para o saber, para o sentir, é necessário ousar, é necessário aproximar o seu rosto da cinza. E soprar devagar para que a brasa, por baixo, recomece a propagar o seu calor, a sua luminosidade, o seu perigo. Como se, da imagem cinzenta, se erguesse uma voz: "Não vês que ainda estou a arder?" (DIDI-HUBERMAN, 2015, p. 317).

As imagens que recolhemos do Onze de Setembro ardem, pois nelas reverberam outros tempos, outros contextos culturais que pairam sobre elas como partes ocultas de uma malha sensível mais ampla. Como a autora Maurizia Natali (2006) aponta, a fórmula patética que é tão evocada por obras de ficção científica de destruição apareceu ao vivo para o mundo naquela manhã de setembro. Elas possuem como condição de existência um incômodo que logo se torna epistemológico em nosso tratamento com elas. Uma inquietação que assombra, que faz ressurgir flashes de uma cultura visual. Elas agenciam uma rede emaranhada de lugares, agitando-os e exigindo nosso olhar para sua incessante capacidade de desafiar e se proliferar.

Peguemos como exemplo a fotografia (Fig. 4) das pessoas encarando as torres em chamas. Elas certamente não estão operando um exercício metalinguístico simples de observar quem as observa. Não, elas se mantêm atônitas, quase petrificadas, minando a noção de movimento dentro da fotografia. Seus olhares são contornados por uma expressão de choque, bocas abertas, olhos sem piscar, pulmões carregados de ar. O tempo parece suspenso pelo caráter extraordinário do evento. 0 medo do que irá acontecer depois. Ao mesmo tempo, todas as cabeças estão inclinadas para cima. Se seus olhos fossem uma câmera, estaríamos observando um plano em contra-plongée, que no cinema é frequentemente utilizado para transmitir uma sensação de grandeza ou de imponência de algo. A imagem que enfeitiçou o campo de visão de nossos personagens é o que exatamente? No nível mais específico de seu contexto, é a imagem das torres queimando; em se tratando de um contexto próprio da imagem, ela pode se configurar como outras coisas. Seria uma nave espacial de outro planeta? Um cometa se aproximando da terra? Um monstro gigante se aproximando? É comum que o cinema recorra aos mesmos olhares (Fig. 7 e 8) quando visa dispor uma série de personagens diante de uma catástrofe iminente. A primeira imagem abaixo é do filme Titanic (James Cameron, 1997), no momento em que uma passageira dos botes observa à distância o navio erguendo-se ao ar com diversas pessoas pulando. A segunda é do filme Independence Day (Roland Emmerich, 1996), e apresenta uma mulher observando uma nave espacial gigante 
que paira - curiosamente - sob Nova lorque. Em instantes a mulher irá morrer por um raio azul disparado pelos conquistadores espaciais.

Figuras 7 e 8 - Olhos atônitos em Titanic e Independence Day

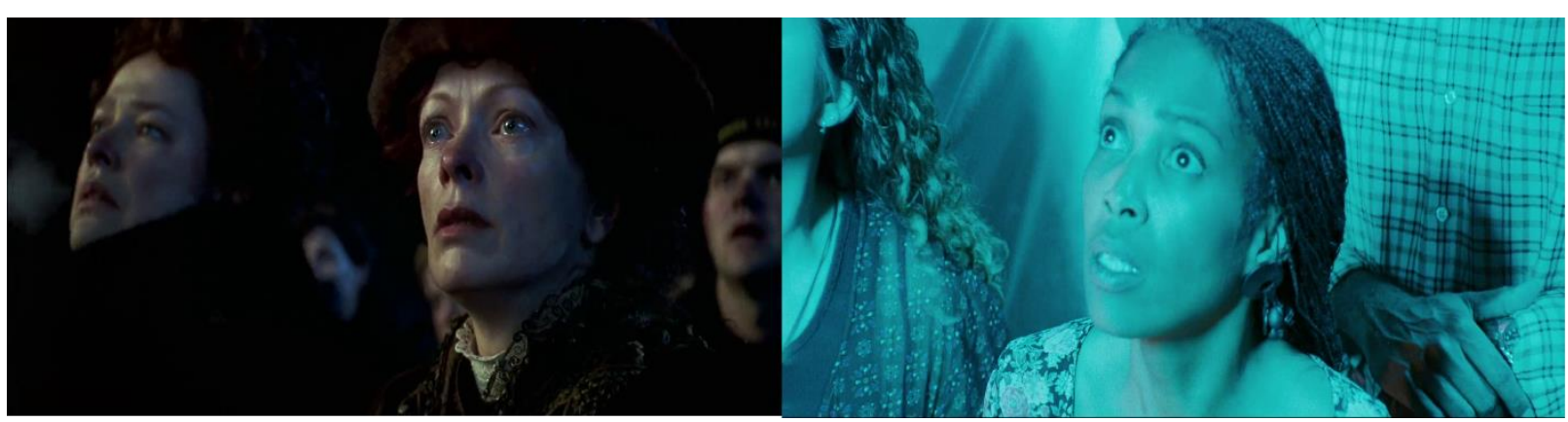

Fonte: Reprodução/Prints dos filmes

O que chama atenção do registro no 11/09 (Fig. 4) é que ela já existia enquanto uma fórmula patética através do cinema, ou seja, já tinha sido encenada. Colocadas juntas, as três imagens (Fig. 4, 7 e 8) se tornam indissociáveis de uma Pathosformel que bagunça linhas temporais e contextos próprios, desenvolvendo assim um pensamento por imagem que coloca as torres gêmeas, uma nave espacial e o desastre do Titanic como sendo simbolicamente muito próximos um do outro. Enquanto imagem, fica difícil que as possibilidades para além do quadro não se multipliquem. Nesse caso, a possibilidade dos cidadãos novaiorquinos (Fig. 4) estarem presenciando um ataque alienígena ou até mesmo a destruição da cidade por um monstro como o Godzilla (Fig. 9) não se torna improvável enquanto imagem.

Figura 4 em relação à Figura 9 - Pessoas petrificadas encaram o Godzilla

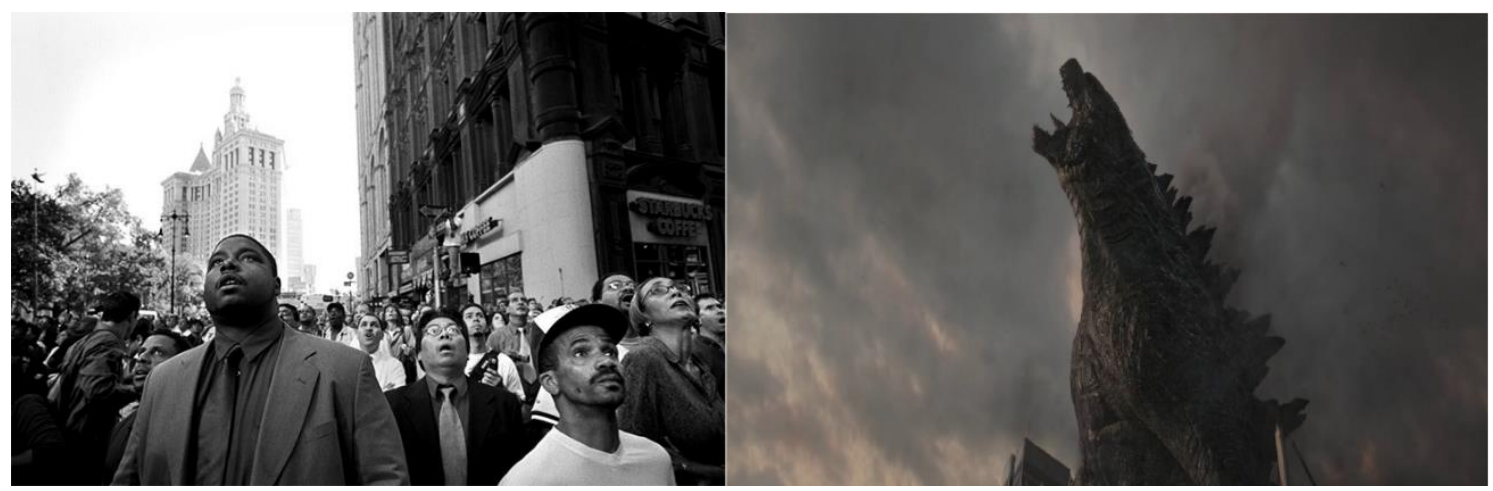

Fonte: Figura 9 - Print do filme Godzilla (Gareth Edwards, 2014)

As imagens não só incentivam essa pré-disposição para além de seu quadro, mas elas a têm enquanto sua condição. A pergunta “o que eles estão vendo?" relativo à figura 4 - se confunde com a nossa pergunta metodológica, "onde eu vi isso?", no sentido de que os olhares tão marcantes, tão urgentes, tão hipnotizados 
da imagem dos novaiorquinos vendo as Torres Gêmeas queimando já surgiram em nosso imaginário nas aparições de Godzillas, Titanics e naves espaciais. Existe um processo recíproco entre esses objetos de fundir suas narrativas em prol de um símbolo comum, o medo diante do fim. O contexto particular do evento ocorrido no World Trade Center (WTC) não funciona como único aporte para compreender a potência dos olhos petrificados (Fig. 4). À luz de Warburg e Didi-Huberman, a imagem não existe senão por resquícios e sobrevivências de outras imagens, e em sua materialidade opera inúmeras memórias e lugares. Nosso caso específico nunca fechará somente em uma montagem com imagens do Godzilla ou nas Torres Gêmeas, estará sempre destinado a vagar por possibilidades, por apostas.

\section{IMAGENS DO FIM DO MUNDO}

Porém, para além do jogo de montagem de um antes e depois, opera-se na imagem a montagem com outras por associação ou por contingência. Nesse aspecto, nossas imagens recolhidas sobre o 11/09 possuem como condição de seu fascínio, como urgência de seu aspecto divisor de águas de imagens contemporâneas, o fato de elas já existirem e já terem surgido sob outros rostos. Funcionando como um centro gravitacional de uma cultura visual anacrônica, o processo de destruição das torres do WTC atualiza uma atração do olho para eventos de destruição em grande escala ao mesmo tempo em que faz reviver passados imagéticos. 0 impacto que essas imagens têm representa a materialização inesperada de muitas outras que pairam sob a cultura do homem, mesmo que não possuamos uma capacidade firme de conectá-las de imediato. Imagens de cinema, simulações sofisticadas de desastres urbanos provocados por alienígenas ou monstros gigantes que surgem em oposição aos homens. O cinema é um meio, por natureza, favorável para se imaginar coisas que não existem, dispositivo produtor de imagens extraordinárias, fins de mundo, cidades consumidas pelo fogo e assim por diante.

Quando nos recordamos da imagem clássica da explosão do avião na segunda torre atingida (Fig. 1), ela se torna tão pungente justamente por se assemelhar a uma recriação sofisticada de algum filme e, no entanto, não ser. Dentro dela, há o nascimento de uma força que consumiu a vida de várias pessoas, tornando suas faces impessoais e ocultas (afinal, não estamos vendo nenhum rosto ou corpo nítido). Entretanto, isso não significa que a presença humana não é sentida nessa imagem. Muitas das imagens que se associam com a explosão da segunda torre relacionam-se com o cinema, pois foi ele que melhor soube materializar esse fim de mundo claustrofóbico.

Em Independence Day, instantes após o close da personagem olhando para a nave espacial (Fig. 8), existe a imagem do prédio (Fig. 10) sendo consumido por chamas após ser atingido por um raio de calor. As similaridades entre os rostos que observavam atônitos (Fig. 7 e 8 ) ressurgem nas imagens dos respectivos 
acontecimentos. Para além de serem prédios em processo de destruição por explosões (e em Nova York), existe um aspecto urgente do presente nessas imagens, como se elas tivessem captado o segundo decisivo de um processo que fascina o olho. O instante do "BOOM!". O contraste da cor. 0 ensurdecedor "bang!" que proporciona a destruição. Existe uma potência em imagens de destruição de grandes objetos construídos pelo homem que é relativa à sua capacidade de nos fazer sentir os sons presentes nelas. O barulho do fogo, dos metais sendo quebrados, o caráter expansivo de uma explosão.

O cinema entendeu bem que tal fórmula não requer a imagem de um prédio em destruição para se materializar, tendo em vista que um ano após o filme de Emmerich, James Cameron a fez ressurgir na figura de um navio que se parte em dois pedaços (Fig. 11) com milhares de pessoas dentro de si. 0 som da explosão cede lugar a vozes desesperadas pela proximidade do fim. A verticalidade some em prol de uma figura inclinada (que com o passar dos minutos se tornará vertical). A popa do navio irá cair em cima de centenas de pessoas que boiam na água gelada. A montagem frenética de Cameron confere uma sensação de espetáculo à cena: gritos longos, música tensa, com pessoas se jogando do navio em um gesto muito próximo aos suicídios do WTC.

Figuras 10 e 11 - Imagens de destruição em Independence Day e Titanic

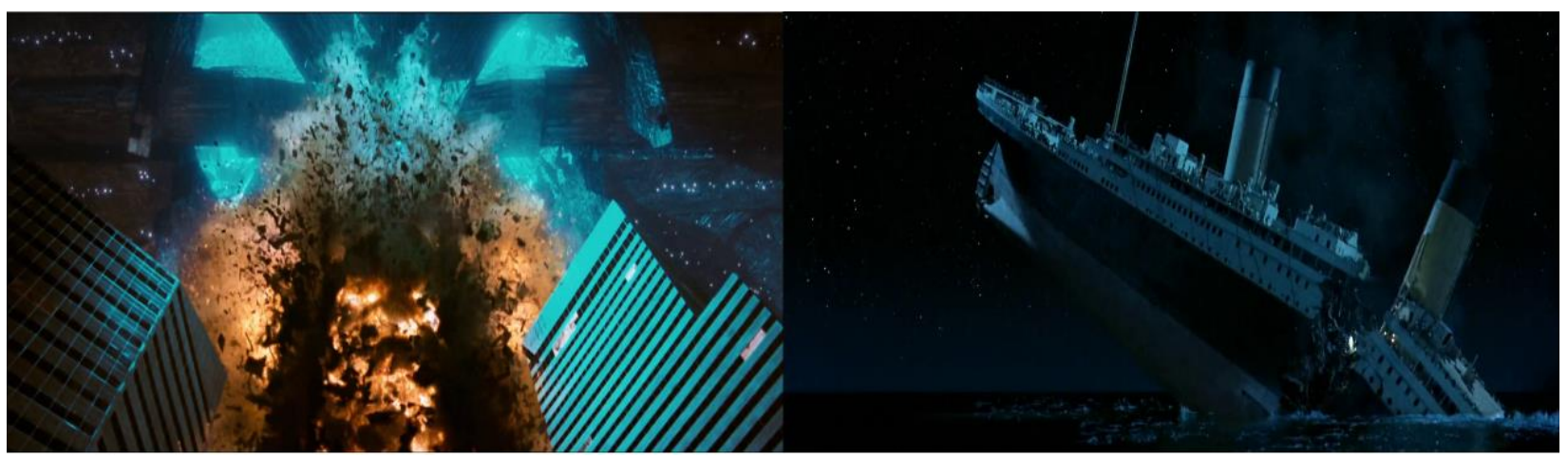

Fonte: Reprodução/Prints dos filmes

Tais exemplos vêm de dois blockbusters que foram sucessos enormes de bilheteria em todo o mundo, que estão separados por menos de cinco anos do atentado ao WTC. 0 cinema compreende o potencial que tal fórmula patética possui para grandes retornos financeiros. Até porque as explosões nas Torres Gêmeas (Fig. 1) não são as primeiras imagens a povoarem um imaginário ocidental de um grande objeto em processo de destruição. Décadas antes, o dirigível LZ 129 Hindenburg (Fig. 12), o maior já construído, pegou fogo ao tentar aterrissar, ocasionando várias fatalidades. No canto inferior da imagem, pessoas observam de longe o desastre (estariam olhando de maneira semelhante aos exemplos que trouxemos?), mostrando o quão pequenas são diante do dirigível. Metade do quadro imagético é composto por uma fumaça negra e por chamas tão brancas que 
parecem ser ressaltadas pelo aspecto acinzentado do lado esquerdo, e pela escuridão do lado direito. Em instantes, o veículo irá cair totalmente no chão, fazendo, por consequência, um tremendo estrondo.

Figura 1 em relação à figura 12 - Fórmula patética em desastres famosos

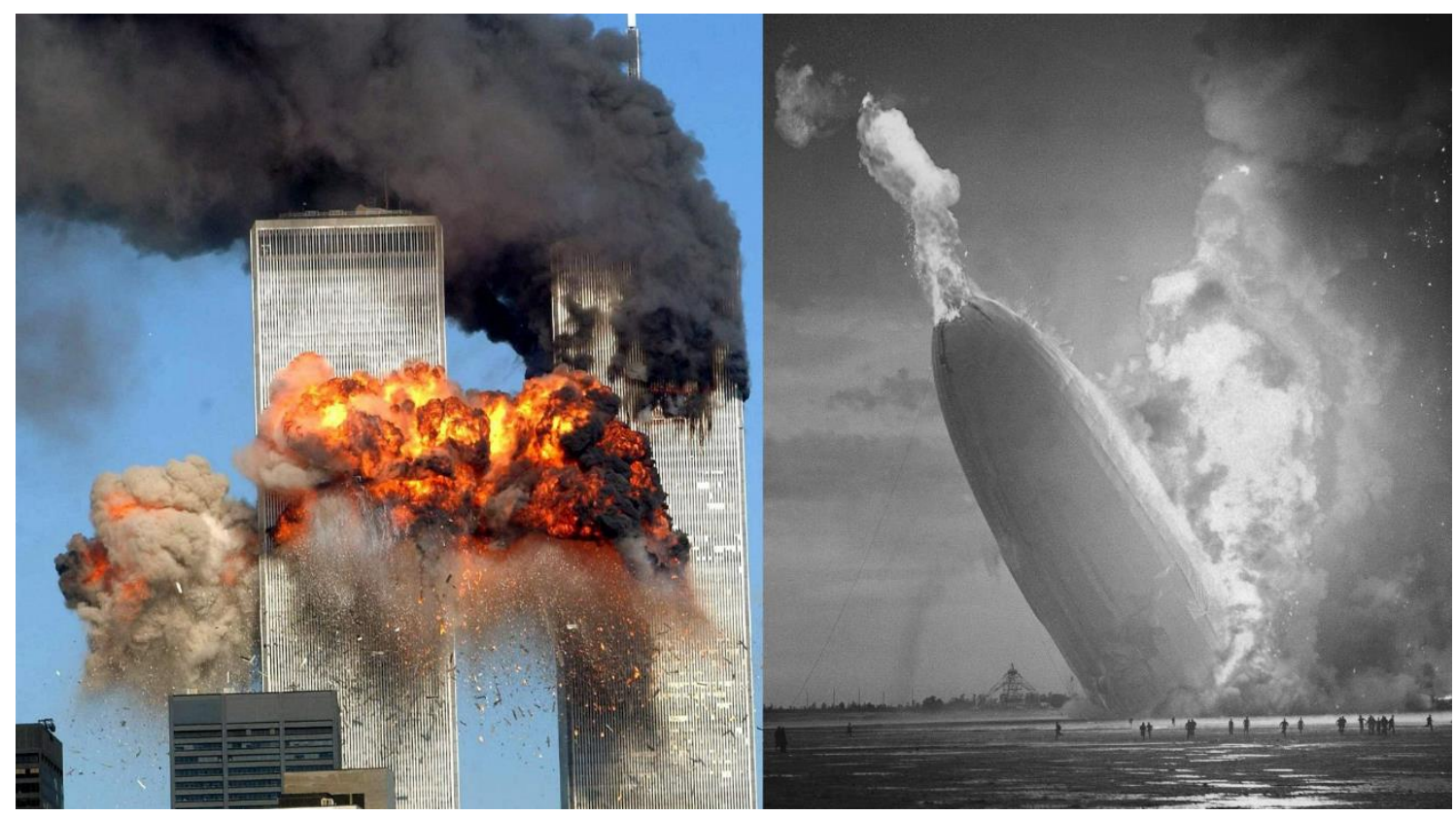

Fonte: Figura 12 - Reprodução/Murray Becker

Diante dessas quatro imagens, um olhar assombrado desenvolve-se. Os seres que as observaram ao vivo permanecem ocultos em metade delas, entretanto todas elas representam pontos de vista de pessoas que estão em uma escala ínfima diante do acontecimento e que estão completamente aquém de qualquer chance de mudar o que se passa diante delas. Rostos destinados a serem espectadores passivos diante de algo superior e atordoante. Imagens que possuem um efeito medusa em seus espectadores (Fig. 4), inibindo seus movimentos em favor de um relacionamento mediado pelo medo de que o acontecimento em questão (e a destruição que ele provoca) se aproxime, apesar de ocorrer à distância. 0 medo da morte. A ausência ou apagamento da figura humana nessas imagens revela uma força indiferente ao homem e, por isso, assustadora. 0 homem se perde diante da fumaça, se torna um detalhe, um empecilho para o fogo, para a fumaça. Imagens atormentadas por dimensões grandiosas, por processos extraordinários, violentas ao olho por estarem, simbolicamente, atreladas à ideia da morte em grande escala.

Entretanto, o impacto do segundo avião no World Trade Center não representa a última instância de uma fórmula patética do fim de mundo nas imagens do Onze de Setembro, pois a queda das torres (Fig. 3, 13 e 14) fez subir uma nuvem de poeira que parecia se espalhar por toda a cidade para engoli-la (Fig. 
13 e 3). Neste momento, não havia espectadores enfeitiçados por imagens grandiosas distantes, mas pessoas que correram (Fig. 3) para salvar suas vidas.

Figuras 13 e 14 (de cima para baixo) em relação com a figura 3 - As torres caem

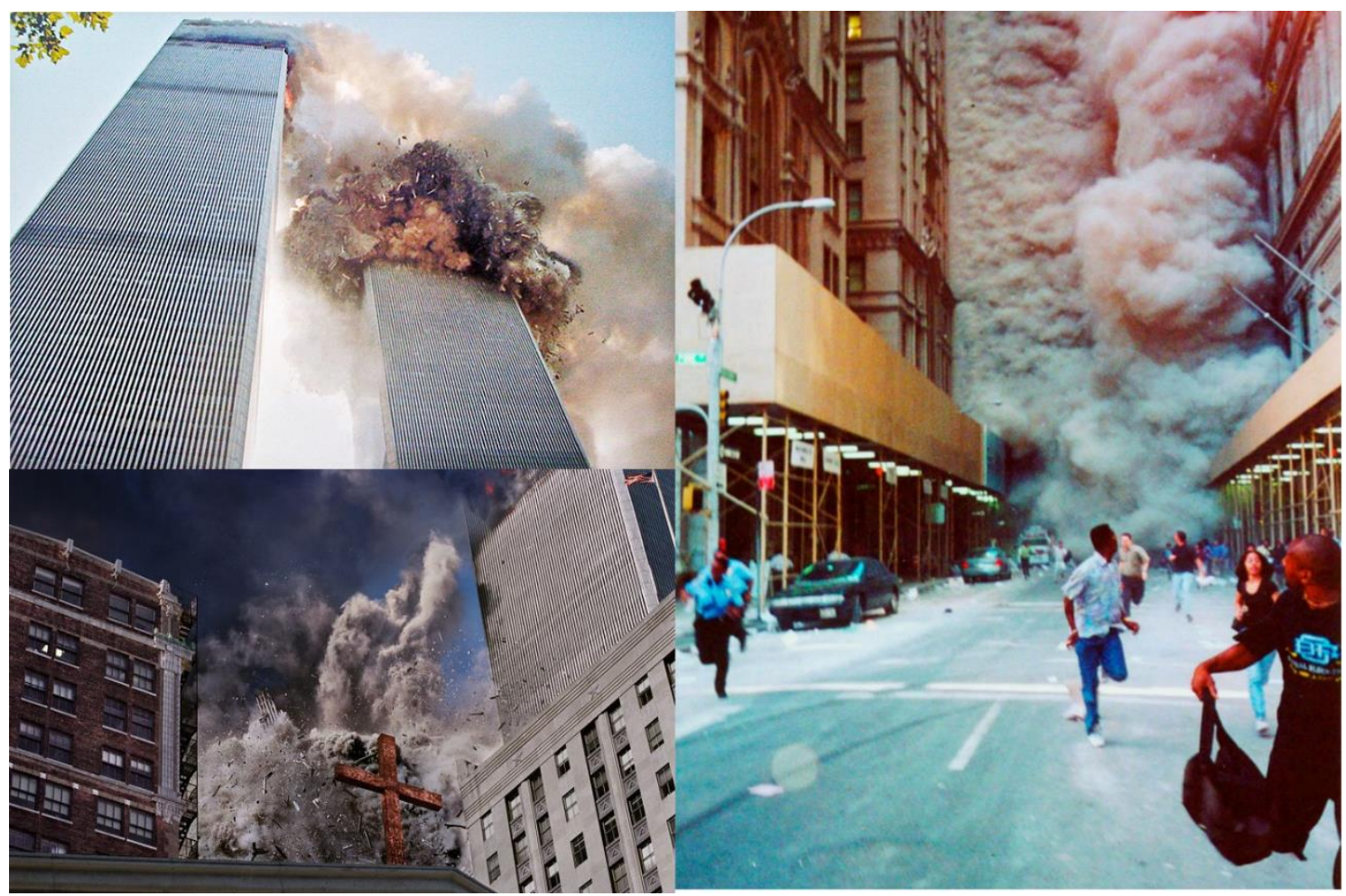

Fonte: Figuras 13 e 14 - Reproduções/James Nachtwey (13) e Bolivar Arellano (14)

Se $o$ avião atingindo a torre representa um primeiro estágio para um evento em progresso, essas últimas três imagens, quando as torres estavam caindo, são envoltas por uma sensação curiosa de claustrofobia, pois a expansão da poeira parece prestes a tomar todo o quadro. Em instantes, o pó irá repintar tais cenas no absoluto da cor cinza, de cima para baixo (Fig. 13), lateralmente (Fig. 14) e frontalmente (Fig. 3). 0 fim pela cor, como se um pintor estivesse a lançar seu material na tela para consumi-la. A poeira enquanto imagem - lembremos de Michaud (2013) - está captada em seu movimento violento de expansão, e, portanto, é uma imagem em processo de ser esticada, alargada.

O cinza é absoluto, é puro. Ele não apenas mancha, ele permanece, sendo volumoso e difícil de ser ignorado nessas imagens, como se a ordem do cenário estivesse mudando, se tornando algo novo. Há um aspecto bastante calcado na ideia do natural nessas imagens, algo próprio do planeta, uma força que surge e se espalha. Um retorno ao primitivismo cru da cor. 0 fim de mundo enquanto uma reestruturação da imagem.

Antes de chegarem a uma estabilidade, os elementos do quadro se debatem de maneira violenta, marcando-o como um palco de forças expressivas que não se 
anulam. Duas pinturas do século XIX, ambas de John Martin, souberam captar tal fórmula patética. A primeira, intitulada "The Great Day of His Wrath", datada de 1851-1853 (Fig. 15): cidades são consumidas pelo fogo e inclinam-se para o centro do mundo enquanto tempestades cortam as bordas da imagem, travando um duelo de cores. No segundo quadro de Martin, "The Fall of Babylon" (Fig. 16), datado de 1831, pessoas se fundem com o caráter negro do quadro que tem, em seus céus acinzentados e nuvens espirais, uma grandeza em comum com a nuvem de poeira do Onze de Setembro (Fig. 3, 13 e 14). Em ambos os quadros, Martin operou o fim de um mundo pela cor e pelas formas geométricas - as laterais de The Great Day... que parecem convergir para o centro, o céu que parece prestes a formar um furacão em Babylon. A dramaticidade em grande escala desses quadros nos atinge pela marca irredutível de seus elementos, o laranja que se transforma em cinza em The Great Day, o negro de Babylon. A cor nesses quadros é uma maneira de entrar nessa realidade, a passagem para um novo desenho de paisagem. Assim como as imagens da torre caindo e da poeira se expandindo, tais quadros são inerentes a uma sensação de volta à terra.

O cinema também chegou a tal fórmula patética, mas se valeu de um evento que, assim como o 11/09, não foi controlado. 0 diretor alemão Werner Herzog rodou o filme-ensaio "Lições da Escuridão" (1992) com imagens dos poços de petróleo em chamas na Guerra do Golfo Pérsico. Boa parte das imagens são aéreas, quase da perspectiva de um olho extraterrestre, acompanhadas por músicas de Wagner e Schubert, ressaltando o tom grandioso e apocalíptico que algumas imagens têm (Fig. 17 e 18). Tais imagens são a materialização do que Martin imaginou, operando pela mesma dramaticidade e impacto que o pintor buscou captar. 0 volume espesso da fumaça preta contorna o pequeno horizonte, ainda razoavelmente azulado (Fig. 17), enquanto outra imagem (Fig. 18) mais parece um zoom do laranja mudando de cor em The Great Day of His Wrath. 
Figuras 15 a 18 (de cima para baixo e da esquerda para direita) -

Fim de mundo pela cor e pelas formas

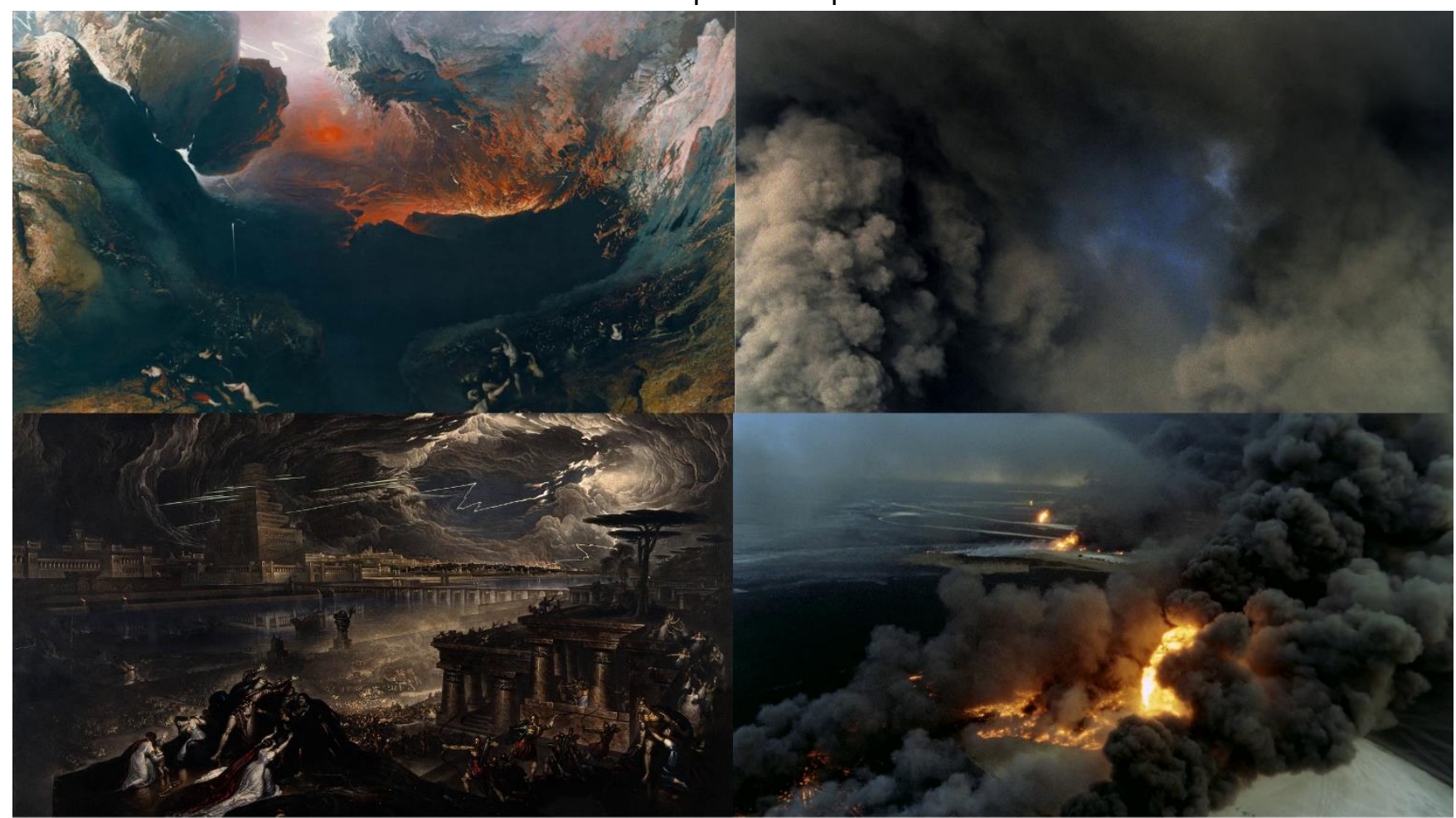

Fonte: Reproduções do Youtube (15 e 16), Prints do filme Lições da Escuridão (17 e 18)

Colocadas em relação com as imagens das torres caindo, os limites entre a fotografia, a pintura e o cinema são reduzidos em prol de uma fórmula patética do fim de mundo que opera através da forma e da cor. Essas imagens promovem uma cultura visual que atravessa contextos e épocas particulares, indicando que imagens do fim de mundo são anacrônicas. 0 caráter fascinante que as imagens do Onze de Setembro possuem reside, em parte, no fato de que a cultura ocidental já estava enraizada em imagens similares. Imagens que quebram a dicotomia de baixa ou alta cultura, imagens estáticas e em movimento. Imagens que eram constantemente sonhadas e que ressurgiram violentamente sob o céu azul de Nova lorque em uma manhã qualquer.

Se a imagem de pessoas fugindo do desastre (Fig. 3) chama atenção por ser tão cinematográfica, isso se dá porque a sétima arte já havia compreendido a eficácia ${ }^{5}$ estética de tal fórmula patética (Fig. 19 e 20). Um contraste se estabelece entre o homem e um elemento, uma maneira de fazer com que os artifícios hollywoodianos - computação gráfica, cortes rápidos, slow motion causem suspense e medo. Hollywood construiu em sua fórmula patética rostos não individualizados, massas desprovidas de suporte narrativo (alguns corpos são

\footnotetext{
${ }^{5}$ Não que o cinema tenha originado tal fórmula patética, mas ela é referenciada, atualizada e comercializada com mais frequência nele do que em outras mídias, especialmente na indústria hollywoodiana, devido ao seu apreço por grandes produções calcadas em efeitos especiais. Tal mídia possui as ferramentas para encenar a pathosformel em questão.
} 
gerados no computador), figurantes prestes a morrer. É assombroso como tal aspecto ressurge na imagem dos novaiorquinos fugindo da fumaça. Nós não vemos seus rostos, apenas olhamos para os movimentos de seus corpos borrados. 0 fotógrafo, em posição de perigo, desejou a imagem antes da vida, como os três sujeitos em diferentes planos de sua imagem que olham para trás, para a imagem espetacular, vista no cinema. Real e não-real se encontram nas operações e mistérios da imagem, e a figura do sujeito que mistura a vontade de correr e a de olhar se repete em duas imagens ( 3 e 20). Seja pela fumaça, pelo fogo ou pela água, todas essas imagens apresentam momentos de desespero de pessoas que reagem instintivamente a uma situação fora do controle.

Figura 3 em relação com as figuras 19 e 20 (de cima para baixo) - Fórmula patética entre a fotografia e o cinema

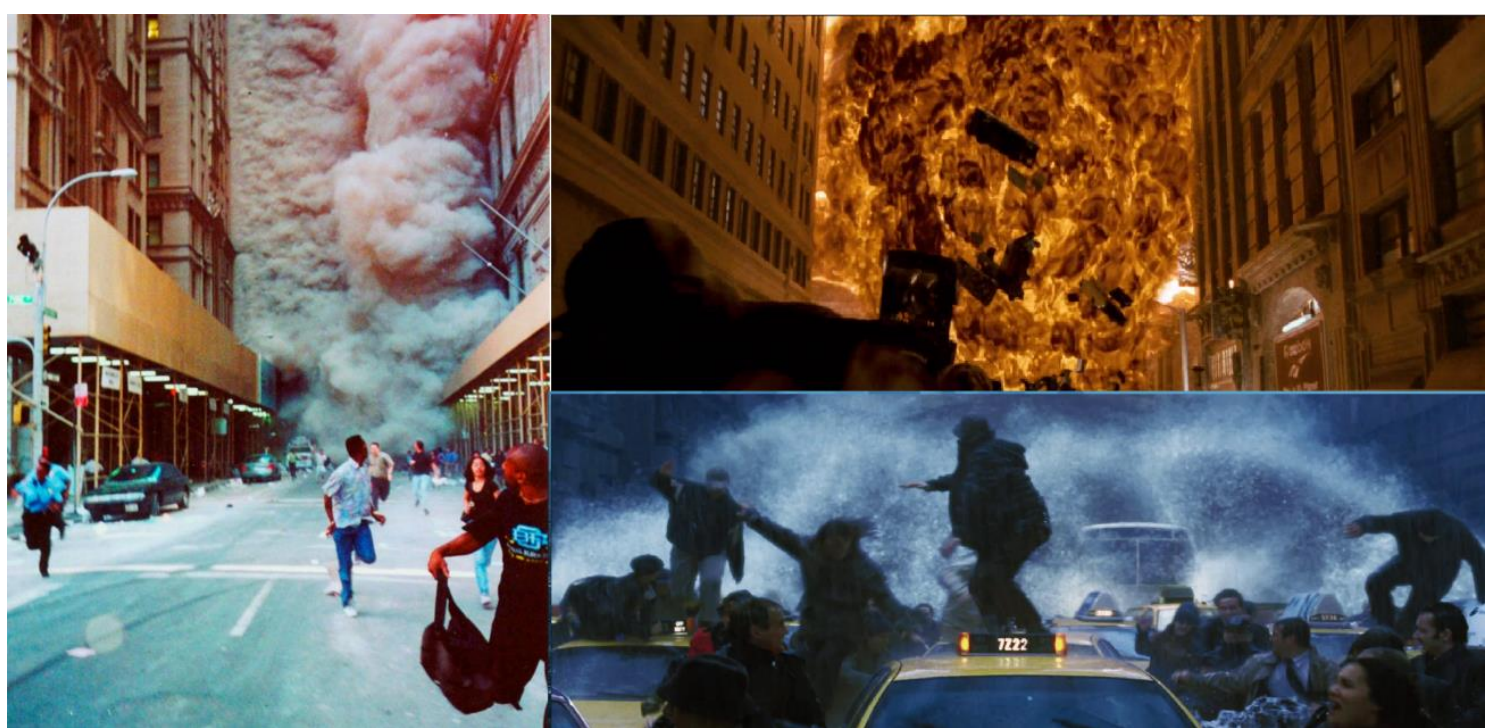

Fonte: Figuras 19 e 20 - Prints dos filmes Independence Day e O Dia Depois do Amanhã (Roland Emmerich, 2004)

No decorrer do acontecimento, as imagens do Onze de Setembro caminharam para uma estabilidade. Elas modificaram uma paisagem, mas após isso alcançaram um aspecto mais desolador. A cidade é pintada de um branco (Fig. 2) onde a poeira se integra à arquitetura, e das nuvens não ecoam mais uma força patética do choque ou do estrondo de uma explosão, mas sussurros da fumaça perdendo a força e se dissipando na cidade. Os prédios se mesclam com a fumaça como se estivessem abandonados, deixados à mercê da catástrofe, como se fossem lembranças de um tempo distante. Caspar David Friedrich fez o céu se confundir com o mar e com a terra na vastidão do horizonte em "Monge à Beira-mar", pintura datada de 1808. 0 monge em questão se perde em meio à reconfiguração do mundo pela cor azul, seu corpo se mescla com o oceano e é acometido pela desolação da paisagem. Colocados em relação, tais exemplos evocam a suspensão 
de um tempo e espaço específicos, fazendo emanar uma inquietação de não sabermos ao certo aonde estamos. 0 homem se perde, se torna um detalhe diante de uma natureza que the é indiferente. 0 fim do acontecimento mais midiatizado do século XXI parece materializar uma imagem tão forte que T.S Eliot vislumbrou no final de um dos poemas mais famosos do século XX, "The Hollow Men", de 1925:

\author{
"Essa é a maneira que o mundo acaba \\ Essa é a maneira que o mundo acaba \\ Essa é a maneira que o mundo acaba \\ Não com um estrondo mas um gemido." 6
}

Figura 2 em relação com a figura 21 - Fórmula patética do fim de mundo entre uma fotografia e a pintura

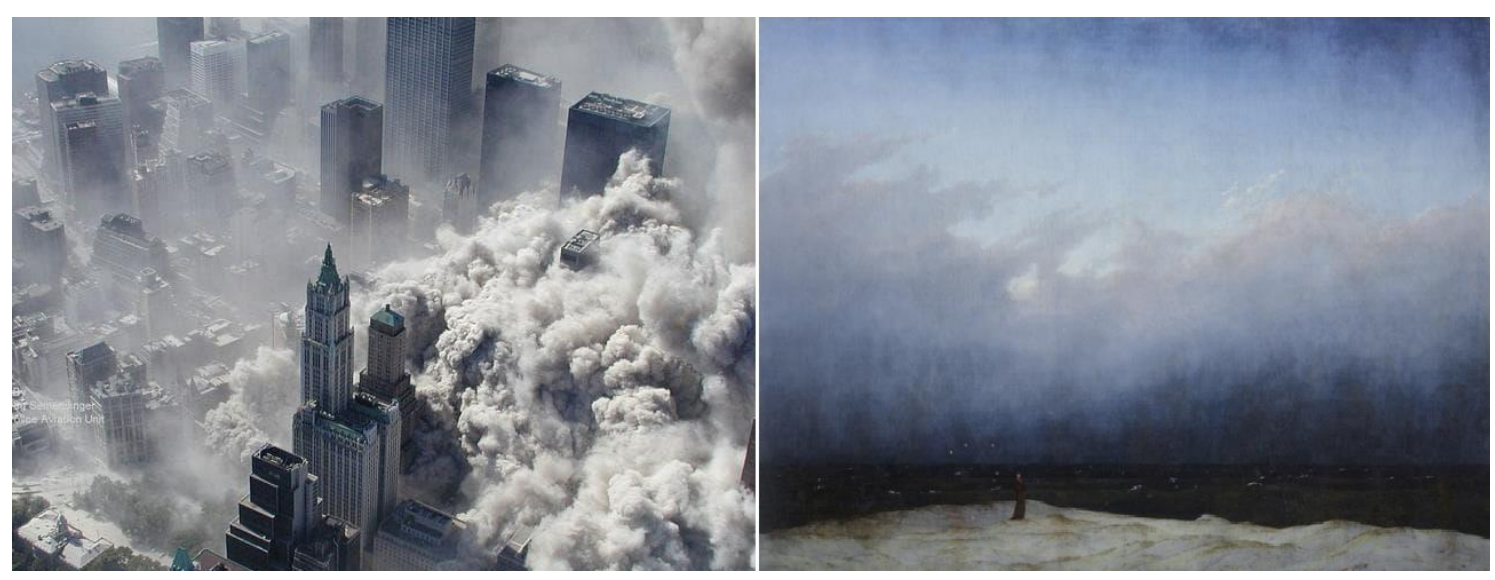

Fonte: Figura 21 - Reprodução da Internet

\title{
REFERÊNCIAS
}

20 Chilling Images From The 9/11 Attacks That You've Probably Never Seen Before. Disponível em: <https://bit.ly/2NhYsPr>. Acesso em 25 de ago. 2018.

BOUTS, Dirk. Head of Christ. Disponível em: <https://bit.ly/207qNNn>. Acesso em 25 de ago. 2018.

BREDEKAMP, Horst. Teoria do Acto Icónico. Lisboa, Portugal: KKYM, 2015.

CAMPOS, Daniela Queiroz. Um saber montado: Georges Didi-Huberman a montar imagem e tempo. Aniki, Portugal, v. 4, n. 2 (2017). Disponível em: <https://bit.ly/2Dy3p4R>. Acesso em: 25 ago. 2018.

DIDI-HUBERMAN, Georges. A imagem sobrevivente: História da arte e tempo dos fantasmas segundo Aby Warburg. Rio de Janeiro: Contraponto, 2013a.

6 "This is the way the world ends, This is the way the world ends, This is the way the world ends, Not with a bang but a whimper" (ELLIOT, T.S, 2015, p. 70) 
$2013 b$.

Georges. Atlas ou a Gaia Ciência Inquieta. Lisboa, Portugal: KKYM, , Georges. Falenas. Lisboa, Portugal: KKYM, 2015.

ELIOT, T.S. Selected Poems. London, UK: Faber \& Faber, 2015.

FRIEDRICH, Caspar David. Monk by the Sea. Disponível em: <https://bit.ly/2Nm7Amg>. Acesso em 25 de ago. 2018.

GINZBURG, Carlo. Medo, reverência, terror. São Paulo: Companhia das Letras, 2014.

Godzilla. [Filme]. Direção de Gareth Edwards, produção de Thomas Tull, Jon Jashni, Mary Parent, Brian Rogers. EUA, 2014. 123 min. Color. Son.

Hindenburg disaster. Murray Becker. Disponível em: <https://bit.ly/2bZ5AAe>. Acesso em 25 de ago. 2018.

Independence Day. [Filme]. Direção de Roland Emmerich, produção de Dean Devlin. EUA, 1996. 145 min. Color. Son.

John Martin: Painter of the Apocalypse. Disponível em: <https://bit.ly/2OZDxAU>. Acesso em 25 de ago. 2018.

LEFEBVRE, Martin (org). Landscape and Film. New York: Routledge, 2006. Lições da Escuridão. [Filme]. Direção de Werner Herzog, produção de Paul Berriff, Werner Herzog, Lucki Stipetić. Alemanha, França, Reino Unido, 1992. 50 min. Color. Son.

Lord Kitchener Propaganda Poster. Disponível em: <https://bit.ly/2zHhk2S>. Acesso em 25 de ago. 2018.

MICHAUD, Philippe-Alain. Aby Warburg e a imagem em movimento. 1 ed. Rio de Janeiro: Contraponto Editora Ltda, 2013.

NATALI, Maurizia. "The course of the empire: sublime landscapes in the american cinema". 2006. In: LEFEBVRE, Martin (org). Landscape and Film. New York: Routledge, 2006, 4, p. 91 - 124.

O Dia Depois de Amanhã. [Filme]. Direção de Roland Emmerich, produção de Roland Emmerich e Mark Gordon. EUA, 2004. 124 min. Color. Son.

PROYMAGO 07 Didi-Huberman. Disponível em: <https://bit.ly/2wuzW6B>. Acesso em 28/08.2018. 
Second plane hits second tower. Getty Images. Disponível em: <https: / / bit.ly/2PBNohq>. Acesso em 25 de ago. 2018.

Titanic. [Filme]. Direção de James Cameron, produção de James Cameron e Jon Landau. EUA, 1997. 195 min. Color. Son.

Visão aérea da cidade de Nova York depois dos atentados. NYPD via ABC News/AP. Disponível em: <https://bit.ly/2MA8HIS>. Acesso em 25 de ago. 2018.

WARBURG, Aby. "Durer e a Antiguidade italiana”. In: WAIZBORT, L (orgs) História de Fantasma para Gente Grande - Escritos, esboços e conferências. Leopoldo Waizbort. Rio de Janeiro: Companhia das Letras, 2015. 